\title{
IDENTIFIKASI DAN ANALISIS AKRILAMIDA DALAM KOPI SERBUK (TUBRUK) DAN KOPI INSTAN DENGAN METODE KROMATOGRAFI CAIR KINERJA TINGGI
}

\author{
M. Hatta Prabowo ${ }^{1 *}$, Ari Wibowo ${ }^{2}$, Fitri Yuliani ${ }^{3}$ \\ ${ }^{1,2,3}$ Program Studi Farmasi Universitas Islam Indonesia \\ *e-mail: htprabowo@gmail.com
}

\begin{abstract}
ABSTRAK
Akrilamida merupakan salah satu zat yang dapat menyebabkan kanker pada manusia dan bersifat neurotoksik. Akrilamida dapat terbentuk akibat pemanasan suhu tinggi terhadap makanan yang mengandung karbohidrat dan asam amino. Karbohidrat dan asam amino merupakan senyawa utama yang terkandung dalam biji kopi. Penelitian ini bertujuan untuk mengetahui jumlah akrilamida pada serbuk kopi dan kopi instan yang beredar di masyarakat. Metode analisa akrilamida dilakukan dengan metode KCKT menggunakan fase gerak asam fosfat:asetonitril:akuabides $\quad(1: 5: 94 \quad \mathrm{v} / \mathrm{v} / \mathrm{v})$, fase diam kolom Sunfire $\mathrm{C}_{18}(150 \times 4,6 \mathrm{~mm}$ id, $5 \mu \mathrm{m})$, dan laju alir $0,15 \mathrm{~mL} /$ menit dengan detektor UV 202 nm. Hasil uji validasi metode yang dilakukan memberikan linearitas 0,999 (range $2-20 \mu \mathrm{g} / \mathrm{mL}$ ), LOD $0,94 \mathrm{~g} / \mathrm{mL}$ dan LOQ $2,86 \mu \mathrm{g} / \mathrm{mL}$, presisi dengan RSD $0,47 \%$, dan akurasi serbuk kopi $91-94 \%$ serta kopi instan 99-102\%. Kadar yang diperoleh menunjukkan kadar akrilamida pada serbuk kopi dan kopi instan masing-masing sebesar 7,03 $\pm 0,01 \mu \mathrm{g} / \mathrm{g}$ dan $5,71 \pm 0,03 \mu \mathrm{g} / \mathrm{g}$. Kadar akrilamida dalam serbuk kopi dan kopi instan dinyatakan aman berdasarkan FDA apabila konsumsi kopi tidak melebihi $16 \mathrm{~g} / \mathrm{hari}$.
\end{abstract}

Kata kunci: akrilamida, serbuk kopi, kopi instan, KCKT, validasi

\section{ABSTRACT}

Acrylamide is a substance that can cause cancer on human and is neurotoxic. Acrylamide is formed due to high temperature heating of foods that contains carbohydrates and amino acids. Carbohydrates and amino acids are the major compounds that contained in coffee beans. This study aims to determine the levels of acrylamide in ground coffee and instant coffee that have different process of manufacture. Method of analyze of acrylamide were perfomed by HPLC (High Performance of Liquid Chromatography) method using mobile phase that consists of phosphoric acid : acetonitrile : aquabides $(1: 5: 94 \mathrm{v} / \mathrm{v} / \mathrm{v})$, the stationary phase was Sunfire $\mathrm{C}_{18}$ column $(150 \times 4.6 \mathrm{~mm}, 5 \mu \mathrm{m})$, and the flow rate was $0-15 \mathrm{~mL} /$ minute and the detection using UV $202 \mathrm{~nm}$. The result of the study was validation of method that provide the linearity 0.999 (range 2-20 $\mu \mathrm{g} / \mathrm{mL}$ ), LOD of $0.94 \mu \mathrm{g} / \mathrm{mL}$ and LOQ of 2.86 $\mu \mathrm{g} / \mathrm{mL}$, the precision with RSD of $0.47 \%$, and accuracy for ground coffee of $91-94 \%$ and instant coffee of $99-102 \%$. The study found acrylamide levels in ground coffee and instant coffee were $7.03 \pm 0.01 \mu \mathrm{g} / \mathrm{g}$ dan 5.71 $\pm 0.03 \mu \mathrm{g} / \mathrm{g}$ respectively. These levels were considered safe for up to $16 \mathrm{~g}$ for consume of coffee.

Keywords : acrylamide, ground coffee, instant coffee, HPLC, validation

\section{PENDAHULUAN}

Menurut Swedish National Food Administration, akrilamid banyak dijumpai pada beberapa makanan berkarbohidrat tinggi yang mengalami pemanasan dengan suhu tinggi (di atas $120^{\circ} \mathrm{C}$ ). Makanan seperti keripik kentang, kentang goreng, popcorn, sereal, biskuit, makanan bayi dan kopi dalam proses pembuatannya mengunakan proses pengolahan dengan suhu yang tinggi. Oleh karena itu, Food and Drug Administration 
(FDA) melarang masyarakat mengkonsumsi makanan-makanan tersebut. Akrilamida dapat juga terbentuk dari protein, peptida, dan amina biogenik (Harahap, 2005). Pembentukan akrilamida juga dipengaruhi oleh beberapa faktor lain yaitu suhu pemanasan, waktu pemanasan, $\mathrm{pH}$, dan kadar air (Lingnert, 2002).

Biji kopi merupakan salah satu produk pangan yang mengandung karbohidrat dan asam amino yang tinggi sebagai prekursor terbentuknya akrilamida. Pembuatan serbuk kopi dilakukan dengan proses roasting kemudian dibentuk bubuk dan apabila dilarutkan dalam air maka akan meninggalkan ampas. Kopi instan dibuat melalui proses roasting kemudian dilakukan grinding lalu dilakukan ekstraksi dengan cara perkolasi pada suhu $154-182^{\circ} \mathrm{C}$. Selanjutnya dilakukan pengeringan (drying) dengan metode spray dryer ataupun freeze dryer (Anonim, 2010).

Karbohidrat dan asam amino merupakan senyawa kimia utama pada kopi sebagai prekursor reaksi Maillard yang berperan penting dalam menimbulkan aroma pada kopi (Seal et al., 2008). Reaksi Maillard adalah reaksi antara senyawa amino (biasanya asam amino, peptide, atau protein) dengan senyawa karbonil. Selama reaksi Maillard dihasilkan zat yang berbahaya seperti akrilamida atau 5hidroksimetil-furfural. FDA menemukan residu akrilamid pada beberapa produk kopi di pasaran (Nursten, 2005). Mekanisme pembentukkan akrilamida dapat dilihat sesuai dengan Gambar 1.

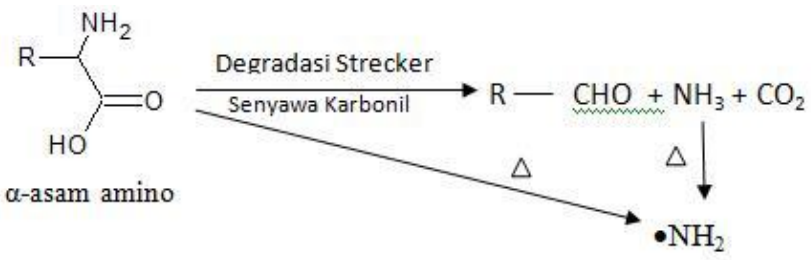

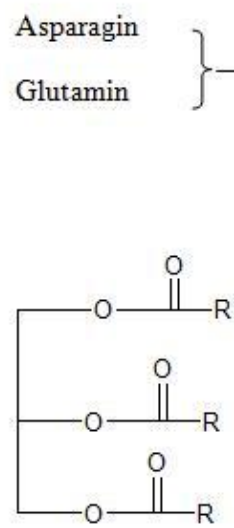

Lipid
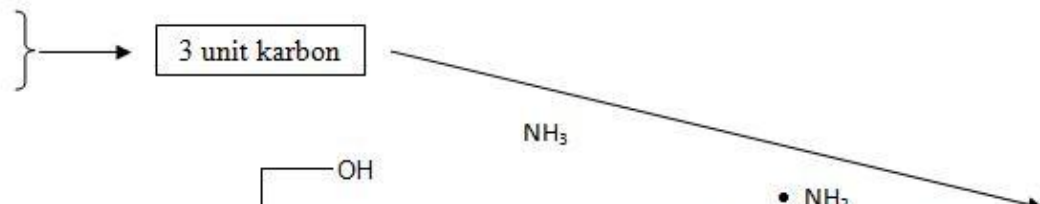
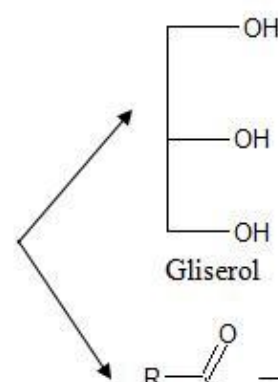

Gliserol

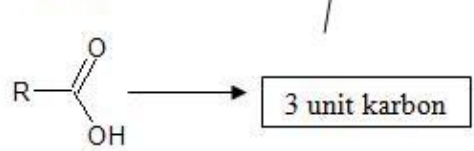

Asam lemak
(O)

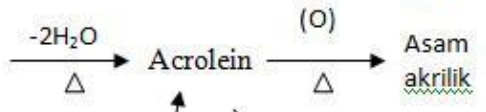

$\mathrm{NH}_{3}$

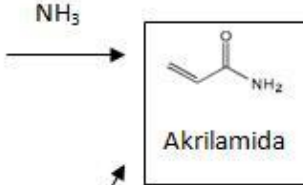

Akrilamida

Gambar 1. Hipotesis mekanisme pembentukan akrilamida dari asam amino dan lipid 
World Health Organization (WHO) menyatakan bahwa pada populasi umum, rata-rata asupan akrilamida melalui makanan berada pada rentang $0,3-0,8 \mu \mathrm{g} / \mathrm{kg} \mathrm{BB} / \mathrm{hari}$. Environmental Protection Agency (EPA) pada tahun 1992 dan WHO pada tahun 1985 telah membatasi kadar akrilamida dalam air minum sebesar 0,5 $\mathrm{\mu g} / \mathrm{L}$ (ppb) (Anonim, 1985). Office of Environmental Health Hazard Assesment (OEAHHA), salah satu divisi EPA yang berlokasi di California, Amerika Serikat telah menetapkan bahwa asupan $0,2 \mu \mathrm{g} / \mathrm{hari}$ akrilamida tidak bersifat sebagai agen pencetus kanker (Anonim, $\left.2005^{\mathrm{a}}\right)$.

Pengembangan metode analisis akrilamida dalam produk pangan telah banyak dilakukan dengan menggunakan metode high performance of liquid chromatography (HPLC) (Liu et al., 2008) dan kromatografi gas (Yasuhara et al., 2003). Analisis dengan menggunakan kromatografi gas membutuhkan tahap derivatisasi akrilamida untuk mengurangi cemaran senyawa lain dan untuk meningkatkan volatilitas, selektivitas dan sensititivitas akrilamida. Namun, tahap tersebut membutuhkan waktu yang cukup lama.

Penelitian yang dilakukan adalah menggunakan kromatografi cair yang tidak memerlukan tahap derivatisasi akrilamida terlebih dahulu, serta tidak membutuhkan pelarut yang bebas air dan bersifat volatil seperti yang dibutuhkan pada analisis dengan kromatografi gas. dan tidak memerlukan waktu yang lama serta merupakan teknik yang baik untuk analisis kuantitatif akrilamida (Liu et al., 2008). Oleh karena itu, penelitian ini bertujuan untuk mengetahui pengaruh proses pengolahan biji kopi terhadap kadar akrilamida dalam produk kopi dengan menggunakan metode kromatografi cair dengan detektor uv yang memiliki validitas dan sensitivitas yang baik.

\section{METODE PENELITIAN}

Bahan yang digunakan pada penelitian ini adalah serbuk kopi (tubruk) dan serbuk kopi instan tanpa tambahan gula yang beredar di pasar di daerah Ngaglik sleman Yogyakarta; akrilamida; aseton (p.a, E Merck, Germany); n-heksana (p.a., E Merck, Germany); asam Fosfat (p.a.,E Merck, Germany); asetronitril (HPLC grade, E Merck, Germany); akuabides (PT. Ikapharmindo Putramas, Indonesia), kertas saring.

Alat yang di gunakan adalah seperangkat alat gelas (Pyrex); ultrasonik $\left(\right.$ Branson $\left.^{\circledR}\right)$; timbangan analitik macrobalance (Metler Toledo ${ }^{\circledR}$ ); timbangan analitik semimikrobalance (Metler Toledo $^{\circledR}$ ); cawan porselen; corong Buchner, vacuum manifold; kaca arloji; detektor UV-Vis (Waters $^{\circledR}$ 2489); kolom $C_{18}$ (Sunfire $^{\mathrm{TM}}$ ) 150 $\mathrm{mm} \times 4,6 \mathrm{~mm}, 5 \mu \mathrm{m}$; injektor, (Waters ${ }^{\circledR}$ SM7); KCKT (Waters ${ }^{\circledR}$ e2695).

\section{Sampling}

Sampel diambil secara acak atau digunakan metode convenience sampling. Sampel yang dipilih adalah produk kopi robusta dengan bentuk sediaan yang berbeda yaitu kopi serbuk (tubruk) dan kopi instan. Kedua sampel dibeli dari supermarket yang ada di wilayah Jalan Kaliurang Yogyakarta dengan batas kadaluarsa yang sama. 


\section{Preparasi sampel}

Sejumlah 2,2 g bubuk kopi ditimbang dan dilakukan penghilangan kandungan lemak dengan menambahkan 10 $\mathrm{mL} n$-heksana pada sampel dan di-vortex selama 5 menit. Setelah didekantasi, residu dikeringkan dengan vacuum manifold. Tahap ini dilakukan 2 kali. Untuk mengekstraksi akrilamida, filtrat kopi yang telah didefatisasi dengan cara ditambahkan aseton sebanyak $20 \mathrm{~mL}$ dan $100 \mu \mathrm{L}$ aquabides dan diultrasonic selama 20 menit pada suhu $40 \pm$ $0,1^{\circ}$ C. Lapisan aseton disaring dengan menggunakan kertas saring dan kemudian diuapkan dengan waterbath. Kemudian residunya ditambahkan dengan $2 \mathrm{~mL}$ fase gerak dan dikocok untuk melarutkan dan disaring dengan kertas saring.

\section{Optimasi kondisi analisa dan uji kesesuaian sistem}

Sejumlah $20 \mu \mathrm{L}$ larutan standar akrilamida dengan 10 ppm diinjeksikan ke dalam sistim KCKT. Fase gerak yang digunakan adalah asam fosfat, asetonitril dan akuabides dengan perbandingan 1:5:94 $\mathrm{v} / \mathrm{v} / \mathrm{v}$ dan laju alir $0,15 \mathrm{~mL} / \mathrm{menit}$ pada panjang gelombang yang sama. Selanjutnya $20 \mu \mathrm{L}$ sampel diinjeksikan ke dalam system KCKT dengan kondisi fase gerak, laju alir dan panjang gelombang $202 \mathrm{~nm}$. Kemudian dari data yang diperoleh ditentukan apakah kondisi yang digunakan memiliki kesesuaian sistem.

\section{Pembuatan standar dan kurva baku akrilamida \\ Sejumlah lebih kurang $10 \mathrm{mg}$ standar akrilamida ditimbang seksama dan dimasukkan ke dalam labu ukur $100 \mathrm{~mL}$. Larutan stok akrilamida dilarutkan dengan asam fase gerak sampai batas. Larutan}

standar akrilamida dengan konsentrasi : 2 ; 5; 10; 15 dan 20 ppm dibuat dengan mengencerkan larutan stok menggunakan fase gerak. Larutan standar 2; 5; 10; 15 dan 20 ppm masing-masing diinjeksikan sebanyak $20 \mu \mathrm{L}$ ke dalam system KCKT pada kondisi terpilih. Luas area dibawah kurva yang diperoleh di hitung untuk menentukan persamaan garis regresi linier.

\section{Pengujian batas deteksi dan batas kuantitasi}

Batas deteksi dan batas kuantitasi ditentukan dari regersi kurva baku yang diperoleh. Nilai LOD $=3,3 \times(\mathrm{SD} / \mathrm{S})$ dan $\mathrm{LOQ}=10 \times(\mathrm{SD} / \mathrm{S})$, standar deviasi $(\mathrm{SD})$ respon ditentukan berdasarkan standar deviasi residual (simpangan baku residual) dari garis regresi yang dinyatakan sebagai $S y / x$ dan $S$ merupakan nilai kemiringan (slope atau b) pada persamaan garis atau regresi linier $y=b x+a$ (Anonim, 2002).

\section{Uji Presisi}

Pengujian presisi yang dilakukan adalah keterulangan (repeatability) sebagai variasi dalam sehari. Kadar yang digunakan dalam pengujian presisi adalah $10 \mathrm{ppm}$ untuk akrilamid. Sejumlah $20 \mu \mathrm{l}$ larutan standar 10 ppm diinjeksikan ke dalam system KCKT menggunakan fase gerak dan kecepatan alir yang terpilih sebanyak 6 kali ripitasi, dielusi dengan eluen terbaik. Data yang akan diperoleh adalah nilai $t_{R}$ dan AUC kemudian dihitung nilai rata-rata $(\overline{\mathrm{x}})$,standar deviasi (SD) dan standar deviasi relatif (RSD). Berdasarkan AOAC, nilai presisi senyawa dengan konsentrasi 100-1000 ppm baik jika \% RSD-nya $\leq 4 \%$ (Anonim, 2002). 


\section{Uji Akurasi}

Sejumlah $22 \mathrm{~g}$ sampel ditimbang dan ditambahkan sejumlah standar yang setara dengan $0,1 \mathrm{mg}$ standar akrilamida. Campuran tersebut kemudian dilakukan defatisasi dengan menggunakan $100 \mathrm{~mL} \mathrm{n}$ hexana dan di-vortex selama 30 menit. Setelah didekantasi, residu dikeringkan dengan vacuum manifold. Defatisasi dilakukan 2 kali. Selanjutnya, campuran yang telah didefatisasi diekstraksi dengan menggunakan $200 \mathrm{~mL}$ aseton, di-ultrasonic selama kurang lebih 1 jam pada suhu $40 \pm$ $0,1^{\circ} \mathrm{C}$. Lapisan aseton disaring dengan menggunakan kertas saring dan kemudian diuapkan dengan waterbath. Kemudian residunya ditambahkan fase gerak hingga 20 $\mathrm{mL}$ dan dikocok untuk melarutkan. Sebelum diinjeksikan, larutan uji disaring terlebih dengan acrodisc syringe filter. Setelah diperoleh data berupa nilai AUC sampel yang telah ditambahkan standar kemudian dihitung \% perolehan kembali dari masingmasing kadar standar yang ditambahkan dalam sampel dengan menentukan persen analit yang ditambahkan yang dapat terukur. Berdasarkan AOAC, nilai \% perolehan kembali senyawa dengan konsentrasi 10100 ppm baik jika nilainya $80-115 \%$ dan konsentrasi 100-1000 ppm nilainya antara $85-110 \%$ (Anonim, 2002).

\section{Uji akrilamida dalam sampel}

Larutan uji hasil preparasi disaring menggunakan acrodisc syringe filter $0,45 \mu \mathrm{m}$ dan diinjeksikan ke dalam sistim KCKT sebanyak $20 \mu \mathrm{L}$ pada kondisi analisis yang sesuai dan ditentukan luas area puncaknya. Konsentrasi akrilamida dalam sampel dihitung menggunakan persamaan kurva kalibrasi.

\section{HASIL DAN PEMBAHASAN}

\section{Uji kesesuaian sistem}

Uji kesesuaian sistem bertujuan untuk memastikan sistem operasi secara lengkap mulai dari instrumen, kolom, reagen dan kolom telah cocok untuk penggunaannya. Uji kesesuaian sistem merupakan bagian integral dari kromatografi cair dan gas. Uji ini digunakan untuk memverifikasi resolusi dan reprodusibilitas sistem kromatografi untuk analisa yang dilakukan. Adapun hasil uji kesesuaian sistem dapat dilihat pada tabel 1. Faktor kapasitas, resolusi, faktor tailing dan efisiensi kolom telah memenuhi persyaratan yang telah di tentukan. Menurut ICH resolusi yang harus dicapai adalah $>1,5$ (Anonim 2005 ${ }^{\mathrm{b}}$ ). Berdasarkan data yang diperoleh, resolusi dari akrilamida masih cukup baik. Menurut FDA, faktor tailing sebaiknya $\leq 2$. Berdasarkan data yang diperoleh, faktor tailing dari akrilamida masih cukup baik. Berdasarkan ketentuan FDA efisiensi kolom akan dikatakan baik apabila nilai $\mathrm{N}>2000$ (Anonim,1994).

\section{Validasi metode analisis}

Validasi metode analisis merupakan suatu tindakan penilaian yang harus dilakukan terhadap parameter tertentu berdasarkan percobaan laboratorium untuk membuktikan bahwa parameter tersebut memenuhi persyaratan untuk penggunaannya. Beberapa parameter analisis yang harus dipertimbangkan dalam validasi metode analisis didefinisikan dan diuraikan sebagaimana cara penentuannya.

\section{Selektivitas}

Selektivitas metode adalah kemampuan suatu metode yang hanya 


\section{Hatta Prabowo}

mengukur zat tertentu saja secara seksama dengan adanya komponen lain yang terdapat dalam sampel. Penentuan selektivitas harus dilakukan selama validasi uji identifikasi, penentuan cemaran dan pengujian.

Prosedur dengan kromatografi digunakan kromatogram standar sebagai pembanding. Kemudian ditentukan resolusi dua puncak yang terelusi berdekatan. Resolusi masing-masing pada sampel kopi serbuk (tubruk) dan kopi instan, pada analisis ini sedikit berbeda. Pada kopi serbuk (tubruk), resolusi rata-rata puncak akrilamida terhadap puncak yang muncul pada menit ke-13,4 adalah 1,9, sedangkan resolusi ratarata puncak akrilamida pada kopi instan terhadap puncak yang muncul pada menit ke-13,4 adalah 2,04. Berdasarkan nilai resolusi tersebut, maka spesifisitas metode yang digunakan sudah baik walaupun baseline kurang baik.

Tabel 1. Hasil uji kesesuaian sistem metode analisa akrilamid dengan KCKT dalam kopi

\begin{tabular}{|c|c|c|c|}
\hline \multirow{2}{*}{ No. } & \multirow{2}{*}{ Variabel } & \multicolumn{2}{|c|}{ Hasil } \\
\hline & & Kopi Serbuk & Kopi Instant \\
\hline 1 & Fase gerak & $\begin{array}{c}\text { Asam fosfat : asetonitril : } \\
\text { akubides }(1: 5: 94)\end{array}$ & $\begin{array}{l}\text { Asam fosfat : asetonitril : } \\
\text { akubides }(1: 5: 94)\end{array}$ \\
\hline 2 & Fase diam & $\begin{array}{c}\text { Sunfire } \mathrm{C}_{18}(150 \mathrm{~mm} \times 4,6 \mathrm{~mm}) \\
5 \mu \mathrm{m}\end{array}$ & $\begin{array}{c}\text { Sunfire } C_{18}(150 \mathrm{~mm} \times 4,6 \mathrm{~mm}) \\
5 \mu \mathrm{m}\end{array}$ \\
\hline 3 & Kecepatan alir & $1,0 \mathrm{~mL} /$ menit & $1,0 \mathrm{~mL} /$ menit \\
\hline 4 & Panjang gelombang & $202 \mathrm{~nm}$ & 202 nm \\
\hline 5 & Faktor kapasitas & 0,65 & 0,96 \\
\hline 6 & Resolusi & 1,90 & 2,04 \\
\hline 7 & Faktor tailing & 0,140 & 0,09 \\
\hline 8 & Efisiensi kolom & 4503 & 7741 \\
\hline
\end{tabular}




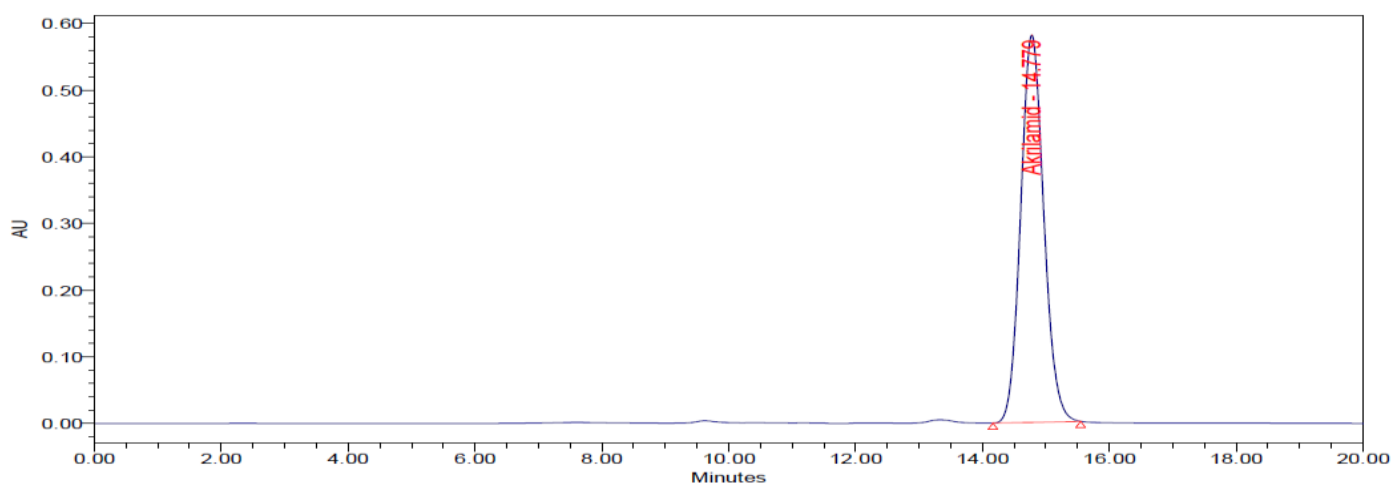

(a)

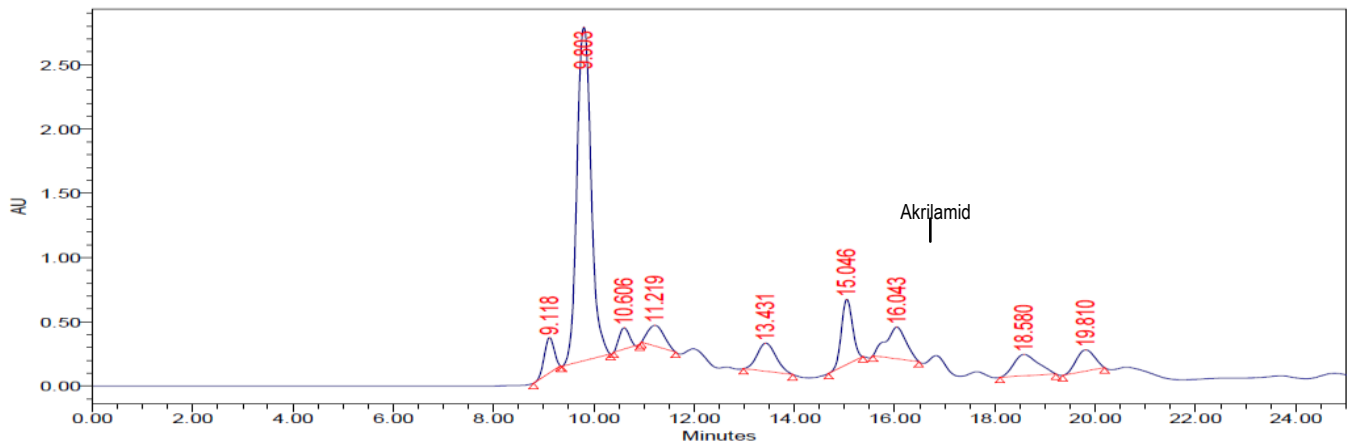

(b)

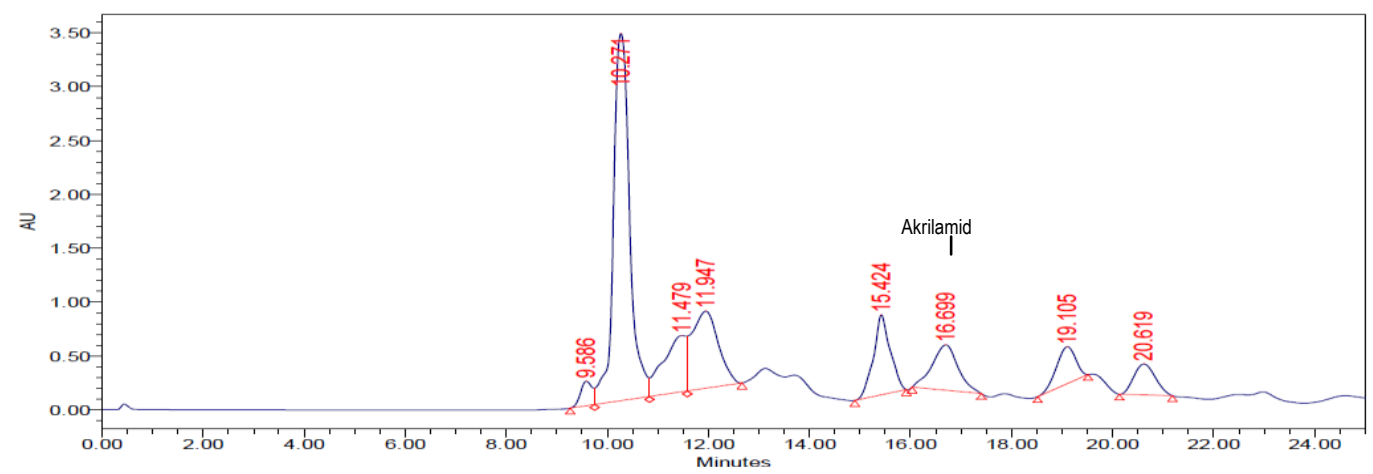

(c)

Gambar 2. (a) Kromatogram standar akrilamida, (b) Kromatogram sampel kopi instan, (c) Kromatogram akrilamida sampel serbuk kopi tubruk. Kondisi KCKT : Kolom Sunfire $\mathrm{C}_{18}(150$ $\mathrm{mm} \times 4,6 \mathrm{~mm}) 5 \mu \mathrm{m}$, fase gerak asam fosfat : asetonitril : aqubides (1:5:94), laju alir 1,0 $\mathrm{mL} /$ menit dan deteksi dengan UV $202 \mathrm{~nm}$. 


\section{Hatta Prabowo}

\section{Linieritas}

Linearitas ditujukan untuk mengetahui kemampuan metode analisis untuk memberikan respon yang secara langsung atau dengan bantuan transformasi matematik yang sesuai terhadap konsentrasi analit dalam sampel. Data hasil regresi linier yang diperoleh memberikan persaman regresi linier $\mathrm{Y}=1463427,341 \mathrm{X}$ 481214,641 dengan nilai $r$ adalah 0,999. Hal ini menunjukkan bahwa kurva baku memiliki linieritas yang baik.

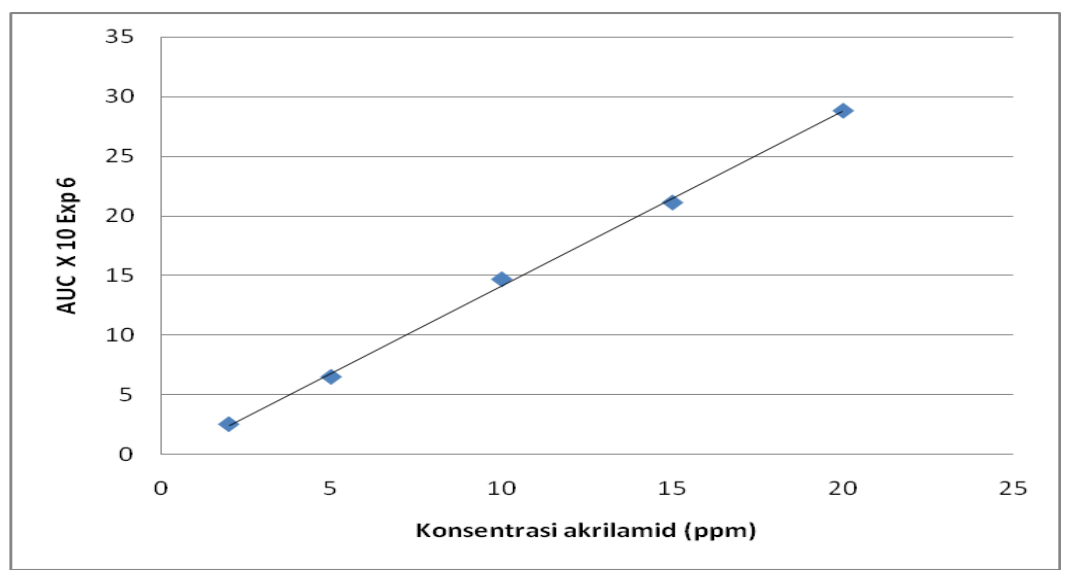

Gambar 3. Kurva kalibrasi akrilamida

\section{Batas deteksi dan batas kuantitasi}

Batas deteksi didefinisikan sebagai konsentrasi analit terendah dalam sampel yang masih dapat dideteksi, meskipun tidak selalu dapat dikuantitasi. Batas kuantitasi merupakan konsentrasi analit terendah dalam sampel yang dapat ditentukan dengan presisi dan akurasi yang dapat diterima pada kondisi operasional metode yang digunakan. Batas deteksi dan batas kuantitasi merupakan parameter sensitivitas suatu metode analisis, semakin kecil nilai batas deteksi dan kuantitasi menandakan semakin sensitif suatu metode dalam menganalisis dan mengukur kadar suatu analit. Berdasarkan hasil perhitungan diperoleh nilai batas deteksi akrilamida adalah $0,79 \mu \mathrm{g} / \mathrm{mL}$, sedangkan nilai batas kuantitasinya adalah $2,40 \mu \mathrm{g} / \mathrm{mL}$.

\section{Presisi}

Presisi merupakan ukuran kedekatan antara serangkaian hasil analisis yang diperoleh dari beberapa kali pengukuran pada sampel homogen yang sama. Presisi biasanya diekspresikan sebagai simpangan baku relatif dari sejumlah sampel yang berbeda sigifikan secara statistik. Keterulangan merupakan ketepatan pada kondisi percobaan yang sama (berulang) baik analisnya, peralatannya, tempatnya, maupun waktunya, sedangkan presisi antara merupakan ketepatan pada kondisi percobaan yang salah satunya berbeda baik analisanya, peralatannya, tempatnya maupun waktunya. Dokumentasi presisi seharusnya mencakup simpangan baku, simpangan baku relatif (RSD) atau koefisien variasi (CV). Merujuk pada Association of Official Analytical Chemist (AOAC) Guidelines yang merupakan acuan dalam validasi metode 
analisis, nilai RSD presisi keterulangan yang diterima untuk senyawa dengan kadar 10 sampai 100 ppm adalah tidak lebih dari 7\% (Anonim, 2002). Data hasil perhitungan presisi pada Tabel 2 menunjukkan bahwa nilai standar deviasi relatif (RSD) dari kadar 6 replikasi adalah $0,47 \%$. Ini menunjukkan $\%$ RSD analit telah memenuhi kriteria yang ditetapkan untuk pengukuran presisi.

Tabel 2. Data uji presisi akrilamida 10 ppm

\begin{tabular}{cccc}
\hline $\begin{array}{c}\text { Penginjeksi } \\
\text { ke- }\end{array}$ & Luas Area & $\begin{array}{c}\text { Kadar } \\
\text { (ppm) }\end{array}$ & $\begin{array}{c}\text { Waktu } \\
\text { Retensi } \\
\text { (menit) }\end{array}$ \\
\hline 1 & 15024858 & 10,62 & 14,83 \\
2 & 15131724 & 10,69 & 14,83 \\
3 & 14938737 & 10,56 & 14,82 \\
4 & 15031849 & 10,62 & 14,83 \\
5 & 14906115 & 10,54 & 14,82 \\
6 & 14953359 & 10,57 & 14,84 \\
Rata-rata & 14997774 & 10,60 & 14,83 \\
SD & 82093,46 & 0,05 & 0,005 \\
RSD (\%) & $\mathbf{0 , 5 4}$ & $\mathbf{0 , 4 7}$ & $\mathbf{0 , 0 3}$ \\
\hline
\end{tabular}

\section{Kecermatan (accuracy)}

Akurasi merupakan kedekatan antara nilai terukur dengan nilai yang diterima sebagai nilai sebenarnya. Akurasi dinyatakan sebagai persen perolehan kembali (recovery) analit yang ditambahkan. Pengukuran akurasi dalam penelitian ini menggunakan metode standar adisi, karena sampel yang dianalisis merupakan obat paten yang tidak diketahui matriks didalamnya sehingga tidak memungkinkan untuk membuat sampel plasebonya. Metode adisi merupakan teknik analisis kuantitatif dengan menambahkan sejumlah analit dengan jumlah yang telah diketahui ke dalam sampel. Persen perolehan kembali ditentukan dengan menentukan berapa persen analit yang ditambahkan tadi dapat ditemukan. Suatu pendekatan praktik dalam metode standar adisi adalah dengan membagi sampel ke dalam beberapa bagian yang sama lalu menambahkan ke dalamnya standar dengan level konsentrasi yang meningkat.

Tabel 3. Uji recovery akrilamida pada kopi serbuk

\begin{tabular}{cccc}
\hline Level & $\begin{array}{c}\text { Kadar akrilamid } \\
\text { teoritik (ppm) }\end{array}$ & $\begin{array}{c}\text { Kadar akrilamid } \\
\text { diperoleh }(\mathrm{ppm})\end{array}$ & \% Recovery \\
\hline $80 \%$ & 12,68 & 11,62 & 91,68 \\
$100 \%$ & 14,08 & 13,34 & 94,74 \\
$120 \%$ & 15,50 & 14,61 & 94,26 \\
\hline
\end{tabular}

Tabel 4. Uji recovery akrilamida pada kopi instan

\begin{tabular}{cccc}
\hline Level & $\begin{array}{c}\text { Kadar akrilamid } \\
\text { teoritik (ppm) }\end{array}$ & $\begin{array}{c}\text { Kadar akrilamid } \\
\text { diperoleh (ppm) }\end{array}$ & \% Recovery \\
\hline $80 \%$ & 10,33 & 10,62 & 102,80 \\
$100 \%$ & 11,48 & 11,54 & 100,52 \\
$120 \%$ & 12,63 & 12,61 & 99,84 \\
\hline
\end{tabular}




\section{Hatta Prabowo}

Merujuk persyaratan nilai akurasi yang tertera dalam AOAC, nilai akurasi yang diterima untuk konsentrasi 1-10 ppm adalah 85-110 \%. Pada uji recovery yang dilakukan terhadap sampel, uji recovery akrilamida dalam kopi serbuk berkisar antara 91-94\% recoveynya sedangkan untuk kopi instan berkisar 99-102\%. Berdasarkan hasil tersebut, maka \% recovery yang diperoleh pada kopi instan dengan menggunakan metode ini dapat diterima.

\section{Penentuan kadar akrilamida pada kopi instan dan kopi tubruk}

Penetapan kadar sampel
merupakan tahap akhir yang dilakukan
dalam penelitian setelah metode baru yang
dikembangkan memiliki validitas yang baik
sehingga hasil pengukurannya dapat
dipertanggungjawabkan kebenarannya.

Tabel 6. Hasil analisis akrilamida dalam sampel kopi instan dan kopi serbuk

\begin{tabular}{ccccccc}
\hline Sampel & $\begin{array}{c}\text { Replikasi } \\
\text { ke- }\end{array}$ & Area & $\begin{array}{c}\text { Kadar } \\
\text { akrilamid } \\
(\mathrm{ppm})\end{array}$ & SD & $\begin{array}{c}\text { RSD } \\
(\%)\end{array}$ & $\begin{array}{c}\text { Kandungan } \\
\text { / sachet }(\mathrm{g})\end{array}$ \\
\hline Kopi & 1 & 9793960 & 7,02 & & & \\
Serbuk & 2 & 9827634 & 7,04 & 0,01 & 0,14 & $7,03 \mu \mathrm{g}$ \\
& 3 & 9803182 & 7,03 & & & \\
Kopi & 1 & 7852027 & 5,69 & & 0,44 & $5,71 \mu \mathrm{g}$ \\
Instan & 2 & 7924334 & 5,74 & 0,02 & 0,74 & \\
\hline
\end{tabular}

Produk kopi serbuk (tubruk) dan kopi instan mengalami langkah pengolahan biji kopi yang berbeda untuk pembuatannya. Kopi tubruk pada umumnya dibuat dari biji kopi yang dipanggang dan kemudian dihaluskan, sedangkan kopi instan dibuat dari biji kopi yang juga mengalami pemanggangan dan dihaluskan dan setelah itu dilakukan perkolasi pada suhu tinggi dengan menggunakan air. Hal ini yang menyebabkan kandungan akrilamid pada kedua jenis kopi tersebut berbeda. Hasil yang diperoleh dari uji tersebut yaitu kopi serbuk (tubruk) memiliki konsentrasi akrilamida yang lebih tinggi. Ada beberapa faktor yang memungkinkan terjadinya penurunan akrilamida dalam proses pembuatan bubuk kopi ini antara lain adalah penyimpanan dan penambahan air pada tahap perkolasi. Diketahui bahwa penyimpanan makanan atau minuman yang mengandung akrilamida pada suhu $>4{ }^{\circ} \mathrm{C}$ akan menyebabkan penurunan konsentrasi akrilamida. Peningkatan kelembaban dengan adanya air menyebabkan penekanan pembentukan akrilamida dan menurunkan kadar senyawa prekursor akrilamida tersebut (Friedman, 2003).

FDA memperkirakan jumlah asupan akrilamida yang masih memberikan tingkat risiko yang rendah adalah $1 \mu \mathrm{g} / \mathrm{hari}$. Kadar tersebut diperkirakan memberikan efek karsinogenik 100.000 kali lebih rendah dibandingkan rata-rata asupan per hari. Asupan akrilamida yang dapat di toleransi adalah 2,6 $\mu \mathrm{g} / \mathrm{kg}$ BB/hari untuk menghindari efek karsinogeniknya. Jika diasumsikan berat rata-rata laki-laki dan perempuan dewasa sekitar 40-80 kg, maka asupan akrilamida yang diperbolehkan adalah 80 - 
$160 \mu \mathrm{g}$ tiap harinya. Pada penelitian ini, diperoleh hasil yaitu kopi instan mengandung akrilamida $7 \pm 0,01 \mu \mathrm{g} / \mathrm{g}$ dan kopi tubruk mengandung akrilamida $5 \pm 0,03 \mu \mathrm{g} / \mathrm{g}$. Berdasarkan data tersebut, maka asupan akrilamida yang diperoleh dari masingmasing kopi dapat dikatakan aman untuk dikonsumsi hingga $16 \mathrm{~g}$ dalam sehari (88$112 \mu \mathrm{g}$ ) pada orang dewasa (Anonim, 2010).

\section{KESIMPULAN}

Metode analisa yang digunakan memiliki validitas yang baik berdasarkan parameter $\mathrm{ICH}$ dan AOAC. Kopi serbuk memiliki kandungan akrilamida 7,03 \pm 0,009 $\mu \mathrm{g} / \mathrm{g}$ dan kopi instan memilki kandungan akrilamid sebesar 5,71 $\pm 0,025 \mu \mathrm{g} / \mathrm{g}$. Kopi serbuk (tubruk) dan instant yang diuji masih relatif aman untuk di konsumsi oleh masyarakat dibawah $16 \mathrm{~g} / \mathrm{hari}$.

\section{DAFTAR PUSTAKA}

Anonim, 1985. Environmental Health Criteria 49 Acrylamide. International Programme on Chemical safety: the joint sponsorship of the United Nations Environment Programme, the International Labour Organisation, and the World Health Organization. http://www.inchem.org/documents/ ehc/ehc/ehc49.htm

\#SubSectionNumber:1.1.5, 13 Juni 201022.00 WIB.

Anonim, 1994, Reviewer Guidance : Validation of Chromatographic Metods, Center for Drug Evaluation and Research (CDER), 22.

Anonim, 2002, AOAC Guidelines for Single Laboratory Validation of Chemical Methods for Dietary Supplements and Botanicals, available at http://www. AOAC.org (diakses 12 Desember 2009).
Anonim, 2005 ${ }^{\mathrm{a}}$. Intake of Acrylamide in Food. Office of Environmental Health Hazard Assesment (OEAHHA). http://oehha.ca.gov/prop65/law/pdf zip /acrylamideintakeReport.pdf, 22 Juni 201021.00 WIB

Anonim, $2005^{\mathrm{b}}$, Validation of Analytical Procedures: Methodology, adopted in 1996, International Conference of Harmonization Q2(R1), Geneva.

Anonim, 2010. Toxicology of Acrylamide (CAS No. 79-06-1) In Support of Summary Information on the Integrated Risk Information System (IRIS). U.S. Environmental Protection Agency Washington, DC

Friedman, M., 2003. Chemistry, Biochemistry, and Safety of Acrylamide. A Review. J. Agric. Food Chem., Vol 51: (16). 45044526.

Harahap, Y., Harmita, Simajuntak, B., 2005, Optimasi Penetapan Kadar Akrilamida yang Ditambahkan ke dalam Keripik Kentang Simulasi Secara Kromatografi Cair Kinerja tinggi, Indonesian J. Pharm., Vol. II No. 3: 154-163.

Lingnert, H., Grivas, S., Jagerstad, M., Skog, K., Tornqvist, M., Aman, P., 2002, Acrylamide in Food: Mechanisms of Formation and Influencing Factor during heating of foods, Scand. J. Nutr., Vol. 46: (4), 159172.

Liu, J., Zhao, G., Yuan, Y., Chen, F., Hu, X., 2008, Quantitative Analysis of Acrylamide in Tea by Liquid Chromatography Coupled with Electrospray Ionization Tandem Mass Spectrometry, Food Chem., Vol. 108. 760-767.

Nursten, H., 2005. The Maillard Reaction Chemistry, Biochemistry and Implications. The Royal Society of Chemistry. Cambridge.

Seal, C. J., de Mul, A., Haverkort, A.J., Franke, K., Lalljie, S.P.D., Mykkanen, H., Reimerdes, E., Scholz, G., Somoza, V., Tuijtelaars, S., van Boekel, M., van Klaveren, J., Wilcockson, S.J., 
M. Hatta Prabowo

Wilms, L., 2008, Risk-Benefit Considerations of Mitigation Measures on Acrylamide Content of Foods-A Case Study on Potatoes, Cereals and Coffee, Brit. J. Nutr.

Yasuhara, A., Tanaka, Y., Hengel, M., dan Shibamoto, T., 2003. Gas Chromatographic Investigation of Acrylamide Formation in Browning Model Systems. J. Agric. Food Chem., vol 51 : 4002-4003. 